\title{
THE LEGAL STATUS OF JERUSALEM UNDER INTERNATIONAL LAW
}

JOHN QUIGLEY

\section{Introduction:}

The 1993 agreement between Palestine and Israel has not solved the issue of the status of Jerusalem. To the contrary, the agreement, in its Article 5 , postpones discussion of the issue until the permanent status negotiations that are to commence in 1996. In 1993-95, Israel has actively built housing for Jews in East Jerusalem.

These efforts at increasing its factual hold on Jerusalem put Israel in violation of international law. When a state undertakes in an international agreement to resolve an issue, it may not subsequently take measures that render the resolution of the issue impossible. International agreements include an element of good faith. States must carry out their international agreements in good faith. Article 26 of the Vienna Convention on the Law of Treaties (1969) states that "Every treaty in force is binding upon the parties to it, and must be performed by them in good faith."

Thus, when Isracl agreed in 1993 to negotiate in 1996 over the status of Jerusalem, it assumed an obligation to do nothing prior to 1996 that would negate the possibility that the negotiations might be conducted in 1996. Israel's construction activity, however, is clearly aimed at creating a series of faits accomplis that will color the 1996 negotiations. Instead of beginning the 1996 negotiations on the basis of the status quo as of 1993, Israel hopes to begin the 1996 negotiations on the basis of the 1996 factual situation, which will be considerably more favorable to it than the 1993 factual situation. 
The illegality involved in Israel's current construction activity must be assessed against the backgound of the overall legal situation of Jerusalem. Even the factual situation as it existed in 1993 did not comport with international norms. Israel had by that date exerted in Jerusalem a degree of control out of keeping with the territorial rights there of the Palestinian people. This paper examines those rights, and the rights asserted by Israel, to determine where sovereignty over Jerusalem properly resides.

\section{Israel's Acquisition of West Jerusalem:}

A key element in any claim to territory is occupation. ${ }^{1}$ Although sovereignty over the area that includes Jerusalem has changed many times from ancient times, the original Canaanite population has continued to inhabit it. That population took on Arab characteristics following the Arab conquest of the seventh century A.D. leading to a change in language and religion.

In addition, a small minority of Jews remained in the area from ancient times. In the late 19 th century, Jews from Europe migrated to Palestine, and many settled in Jerusalcm, so that by 1900 Jews constituted half of Jerusalem's population. ${ }^{2}$

After World War I, Great Britain permitted an additional influx of European Jews, giving Jews a slight majority in Jerusalem. Arabs, however, continued to own the majority of the land in Jerusalem. ${ }^{3}$

In November 1947, the United Nations General Assembly recommended dividing Palestine into an Arab and a Jewish state, and making Jerusalem a corpus separatum, under the U.N. Trusteeship Council. ${ }^{4}$ Intercommunal hostilities followed, and in the Jerusalem area the military initiative was taken by the Jewish forces. The Irgun, a Jewish military

\footnotetext{
${ }^{1}$ R.Y. Jennings, The Acquisition of Territory in International Law, pp. 16-35 (1963). Minquiers and Ecrehos case (France vs. U. K.), Reports of the International Court of Justice 1953, p. 57. Western Sahara (advisory opinion), Reports of the International Court of Justice 1975 p. 3, pp. 40-68. Island of Palmas, U.N. Reports of International Arbitral Awards, vol. 2 , p. 829 (1928).

${ }^{2}$ A History of the Jewish People, pp. 916-917 (Ben-Sasson editor, 1976).

${ }^{3}$ Supplement to the Survey of Palestine 13 (Government Printer, Jerusalem, 1947) (giving as estimates for Dec. 31, 1946, in Jerusalem, 99,000 Jews and 65,000). Henry Cattan, Jerusalem, p. 158 (1981).

${ }^{4}$ General Assembly Resolution 181, Official Records, 2nd session, Resolutions p. 131, pt. 3, U.N. Doc. A/519 (1947).
} 
organization seeking Jewish statehood in Palestine, attacked Jerusalem. Irgun leader Menachem Begin described how "for three days, from 11th to 13th December [1947]," the Irgun "hammered at concentrations of rioters and their offensive bases," by which he meant Arab villages. Begin recounted, "We attacked again and again in Jerusalem. ${ }^{.5}$

On January 5,1948 , the Haganah, the military organization of the Jewish Agency, set a bomb in the Semiramis Hotel in an Arab district of West Jerusalem, killing 26 persons. The Haganah said in justification that the hotel housed Arab irregulars. The British government, however, condemned the Semiramis bombing as terrorist and a "dastardly and wholesale murder of innocent people." 6 In late January 1948, the Irgun Command selected four major Palestine Arab population centers as targets for a spring offensive: Jerusalem, Jaffa, the Lydda-Ramleh area, and the Triangle. ${ }^{7}$

In January-February, under the pressure of the Haganah-Irgun attacks, many Palestine Arabs fled Jerusalem. The Haganah rocketed Arab neighborhoods in Jerusalem, with the apparent aim of frightening Arab residents into fleeing. ${ }^{8}$

In a February 7 speech, Ben Gurion said, "Since Jerusalem's destruction in the days of the Romans, it hasn't been so Jewish as it is now." In "many Arab districts" in the western part of Jerusalem, he said, "one sees not one Arab. I do not assume that this will change." 9 On February 12, after a Jewish woman was shot in the Talbieh district of West Jerusalem, a Haganah loudspeaker van drove through the neighborhood, ordering the Arab residents to evacuate. ${ }^{10}$

In April 1948, combatans of the Irgun and the Stern Gang (LEHI), another Jewish military force, captured the village of Deir Yassin, just west of Jerusalem, and killed about 250 of its civilian inhabitants. The Irgun claimed that it killed the inhabitants while taking houses by force, but witnesses said that it killed them after the fighting ended. ${ }^{11}$ The Irgun drove

\footnotetext{
${ }^{5}$ Menachem Begin, The Revolt pp. 337-38 (1951).

${ }^{6}$ Sam Pope Brewer, "Britain Condemns Haganah 'Murders'", New York Times, January 7, 1948, p. Al.

${ }^{7}$ Begin, supra note 5 , p. 348 .

${ }^{8}$ Benny Morris, The Birth of the Palestinian Refuge Problem: 1946-1949. pp. 50-52 (1987).

${ }^{9}$ Tom Segev, 1949: The First Israelis, p. 25 (1986). Morris, supra note 8, p. 52 .

${ }^{10}$ Morris, supra note 8 , p. 52 .

${ }^{11}$ Dana Adams Schmidt, "200 Arabs Killed, Stronghold Taken", New York Times, April 10, 1948, p. A6. Begin, supra note 5, pp. 162-165.
} 
surviving Deir Yassin inhabitants in trucks through Jerusalem, as a demonstration to Jerusalem's Arabs, ${ }^{12}$ then killed these survivors. ${ }^{13}$ In the days and weeks that followed, the Haganah drove loudspeaker vans around Jerusalem, announcing in Arabic, "unless you leave your homes, the fate of Deir Yassin will be your fate."14

After the Jewish Agency, in May 1948, declared statehood for a Jewish state, hostilities continued around Jerusalem. The Transjordanian Legion and the Israel Defense Force fought inconclusively, then divided the city east and west. By late 1948 Jerusalem's pre-1948 Arab population of 70,000 was reduced to only $3,500.15$

In December 1949, after admitting Israel to membership in the United Nations, the General Assembly again proposed the internationalization of Jerusalem under the U.N. Trusteeship Council. ${ }^{16}$

In 1950 the government of Israel made West Jerusalem its capital city. ${ }^{17}$ Jordan formally incorporated the West Bank, including East Jerusalem. Jordan's parliament said, however, that it acted "withcut prejudicing the final settlement of Palestine's just case within the sphere of national aspirations, inter-Arab co-operation and and international justice." 18

${ }^{12}$ Herry Levin, I Saw the Battle of Jerusalem, p. 37 (1950).

${ }^{13}$ Michael Palumbo, The Palestinian Catastrophe, p. 52 (1987). Avi Shlaim, Collusion Acress the Jordan: King Abdullah, the Zionist Movement, and the Partition of Palestine, p. 164 (1988).

${ }^{14}$ Erskine Childers, "The Wordless Wish: From Citizens to Refugees," in The Transformation of Palestine: Essays on the Origin and Development of the Arab-Israeli Conflict, p. 186 (tbrahim AbuLughod editor, 1971).

15 Ian Lustick, "The Quiescent Palestinians: The System of Control over Arabs in Israel", in The Sociology of the Palestinians, p. 66 (Khalil Nakhleh \& Elia Zureik editors, 1980).

16 General Assembly Resolution 303, Official Records, 4th session, Resolutions p. 25, U.N. Doc. A/1251 (1949).

${ }^{17}$ Emergency Regulations (Land Requisition - Accommodation of State Institutions in Jerusalem) (Continuance in Force of Orders) Law, Laws of the State of Israel, vol. 4, p. 106 (1950). "Jerusalem Named Capital of Israel", New York Times, January 24, 1950, p. A1.

18 Albion Ross, "Amman Parliament Vote Unites Arab Palestine and Transjordan", New York Times, April 25, 1950, p. A1. 


\section{Israel's Acquisition of East Jerusalem:}

In 1967, in hostilities with neighboring states, Israel captured the West Bank, including East Jerusalem. The hostilities grew out of tension between Israel and Syria. On May 13 Prime Minister Levi Eshkol threatened to invade Syria. ${ }^{19}$ Syria complained to the Security Council. ${ }^{20}$ Egypt asked the U.N. to remove its peacekeeping force from the Israel-Egypt border, so that Egypt could move against Israel "the moment it might carry out any aggressive action against any Arab country." 21 U.N. Secretary General U Thant pulled the U.N. force out of Egypt and asked Israel to accept it on its side of the border as a guard against a possible attack by Egypt, but Israel declined. $^{22}$

On June 4, 1967, Israel's cabinet authorized an invasion of Egypt, ${ }^{23}$ and the next day Israel attacked Egypt. Jordan retaliated by shelling into Israel around Jerusalem. At the U.N. Security Council, Egypt charged Israel with aggression, but Israel claimed that Egypt struck first. ${ }^{24}$

Israeli Foreign Minister Abba Eban told the Council, "Egyptian forces engaged us by air and land, bombarding the villages of Kissufim, Nahal-Oz and Ein Hashelosha," and "approaching Egyptian aircraft appeared on our radar screens." 25 In fact, Egypt did not bombard, and its aircraft did not leave their bases. In its advance against Jordanian forces, the I.D.F. captured East Jerusalem.

${ }^{19}$ Charles Yost, "How the Arab-Israeli War Began", Foreign Affairs, vol. 46, p. 307 (1967). Weekly News Bulletin (Government of Israel), May 9. 15, 1967, p. 20, in Amos Shapira, "The Six-Day War and the Right of SelfDefence," Israel Law Review, vol. 6, p. 66 (1971).

${ }^{20}$ U.N. Security Council Official Records, 22nd year, Supplement for April, May, June 1967, p. 90, U.N. Doc. S/7885 (1967) (letter from Syria to President of Security Council, May 15, 1967).

${ }^{21}$ Indar Jit Rikhye, The Sinai Blunder: Withdrawal of the United Nations Emergency Force Leading to the Six-Day War of June 1967 p. 16 (1980).

${ }^{22}$ U.N. General Assembly Official Records, 5th emergency special session, Report of the Secretary-General on the Withdrawal of the United Nations Emergency Force, June 26, 1967, para. 21, U.N. Doc. A/6730/Add. 2 (1967).

${ }^{23}$ Asher Wallfish, "Meir Reveals Text of War Decision", Jerusalem Post, June 5,1972, p. 1.

${ }^{24}$ U.N. Security Council Official Records, 22nd year, 1347th meeting pp. 1-4, U.N. Doc. S/PV.1347 (1967).

${ }^{25}$ U.N. Security Council Official Records, 22nd year, 1348 th meeting p. 15 , U.N. Doc. S/PV.1348 (1967). 
On July 7 Prime Minister Levi Eshkol acknowledged that Israel struck first but said it had done so in "legitimate defense," because it anticipated an imminent Egyptian attack. ${ }^{26}$ Israeli officials said later, however, that Israel had not expected an attack. Itzhak Rabin, who at the time was Israel's Chief of Staff, said that "the two divisions" Egypt sent to the border "would not have been enough to unleash an offensive against Israel. He knew it and we knew it." 27

Jordan's military action against Israel was lawful under Article 51 of the U.N. Charter, as an act of the collective defense of Egypt. Israel's use of force against Jordan was part of its aggression against Egypt, and was therefore unlawful. Thus, Israel took East Jerusalem through aggression. Under the U.N. Charter, Article 2, paragraph 4, territory may not be taken by aggression, and once taken must be returned.

Israel captured East Jerusalem by military action, and, under international law, seizure of territory in the course of hostilities does not give title to that territory. This rule applies whether the military action leading to the seizure was aggressive or defensive. The United Nations considers East Jerusalem to be territory under Isracl's belligerent occupation. ${ }^{28}$

Although Israel had no legal basis for asserting title in East Jerusalem, it tried to alter its legal status. The Knesset decreed that "the law, jurisdiction and administration of the state" of Israel "shall extend to any area of Eretz Israel [the Land of Israel] designated by the Government by order." 29 Using this statute, the government declared Isracli law applicable to an area that included East Jerusalem, plus adjacent West Bank territory of

26"Admission on Attack," Times (London), July 8, 1967, p. 3.

27 "Le général Rabin, ne pense pas que Nasser voulait la querre," Le Monde, Feb. 29, 1968, p. 1.

28 John Dugard, Recognition and the United Nations, pp. 111-115 (1987). Antonio Cassese, "Legal Considerations on the International Status of Jerusalem," Palestine Year Book of International Law, vol. 3, pp. 28-32 (1986)

${ }^{29}$ Law and Administration Ordinance (Amendment No. 11) Law, Laws of the State of Israel, vol. 21, p. 75 (1967). By a simultaneous law, the Knesset gave the Minister of the Interior the right to extend the boundarics of a municipality to include the area designated by government order issued under this amendment. Municipalities Ordinance (Amendment No. 6) Law, 21 Laws of the State of Israel 75 (1967). By order, the Minister of the Interior expanded the borders of east Jerusalem, Kovetz. HaTakanot (Official Gazette), No. 2063, June 28, 1967, p. 2670. 
approximately equal size. ${ }^{30}$ The Israeli Government then merged this newly enlarged East Jerusalem area with West Jerusalem, in an effort to make Jerusalem a single entity. ${ }^{31}$

The 1967 legislation and decrees, however, did not claim Israeli sovereignty in East Jerusalem. In a letter to the Secretary-General, Foreign Minister Abba Eban said, "The measures adopted relate to the integration of Jerusalem in the administrative and municipal spheres, and furnish a legal basis for the protection of the Holy Places of Jerusalem."

At the United Nations, Isracl's extension of jurisdiction was deemed a de facto annexation and was condemned as such. ${ }^{32}$ Eban replied in a letter to the United Nations that the term "annexation" was "out of place." ${ }^{33}$ Israel argued that the 1967 legislation and decrees did not violate the law of belligerent occupation. ${ }^{34}$ But the law of belligerent occupation precludes the annexation of occupied territory and, even in the absence of annexation, forbids the substitution of the occupier's law for the law previously in force. ${ }^{35}$

${ }^{30}$ Kovetz HaTakanot (Official Gazette), No. 2064, June 28, 1967, p. 2690 , in Sabri Jiryis, "Israeli Laws as Regards Jerusalem," in The Legal Aspects of the Palestine Problem with Special Regard to the Question of Jerusalem 181, 182 (Hans Köchler editor, 1981).

${ }^{31}$ Municipalities Ordinance (Declaration of the Enlargement of Jerusalem's City Limits), Kovetz Ha-Takanot (Official Gazette), No. 2065, June 28, 1967, p. 2694, reprinted in "Order Unites Holy City," Jerusalem Post, June 29, 1967, p. 1.

${ }^{32}$ Security Council Resolution 252, U.N. Security Council Official Records, 23nd year, Resolutions \& Decisions p. 9, U.N. Doc. S/INF/23/Rev. 1 (1968). Security Council Resolution 267, 24 U.N. Security Council Official Records, 24th year, Resolutions and Decisions p. 3, U.N. Doc. S/INF/24/Rev. 1 (1969). General Assembly Resolution 2253, U.N. General Assembly Officials Records, 5th emergency special session, Resolution p. 4, U.N. Doc. A/6798 (1967)

${ }^{33}$ Report of the Secretary-General p. 3, July 10, 1967, U.N. Doc. A/6753 (1967).

${ }^{34}$ Elihu Lauterpacht, Jerusalem and the Holy Places, p. 50 (1968).

35 Convention Respecting the Laws and Customs of War on Land, Oct. 18, 1907. Annex: Regulations Respecting the Laws and Customs of War on Land, art. 43, Bevans, Treaties and Other International Agreements of the United States of America 1776-1949, vol. 1, p. 631 (1968). Convention Relative to the Treatment of Civilian Persons in Time of War, art. 64, August 12, 1949, U.N. Treaty Series, vol. 75 , p. $287(1950$ 
The Israeli Government built apartment complexes in East Jerusalem, to encircle, on the eastern side, the areas of Arab population. ${ }^{36}$ This created a Jewish-populated buffer zone between East Jerusalem and the rest of the West Bank. ${ }^{3 \dagger}$

In 1973 the Knesset took a further step towards the incorporation of east Jerusalem when it made East Jerusalem residents, Jewish or Arab, eligible to vote in Jerusalem municipal elections. ${ }^{38}$ Few Arab residents did so, because of their objection to Israel's attempt to merge of East Jerusalem with West Jerusalem. 39

In 1980 the Knesset took still another step towards the incorporation of East Jerusalem when it declared "Jerusalem, complete and united" to be "the capital of Israel." 40 This legislation by implication was a claim of sovereignty over both sides of Jerusalem. The United Nations declared this law a nullity, as a violation of the rules of belligerent occupation. ${ }^{41}$

In 1988 Jordan renounced its 1952 incorporation of the West Bank, including East Jerusalem. King Hussein explained, "We respect the wish of the P.L.O. for an independent Palestinian state." 42 The Palestine National Council then proclaimed "the establishment of the State of Palestine on our

${ }^{36}$ Sarah Graham-Brown, "The Economic Consequences of the Occupation," in Occupation. Israel Over Palestine p. 205 (Naseer Aruri editor, 1983).

${ }^{37}$ Rafik Halabi, The West Bank Story, p. 42 (1982). W. Thomas Mallison \& Sally V. Mallison, The Palestine Problem in International Law and World Order, p. 234 (1986).

${ }^{38}$ Local Authorities (Elections) (Amendment No. 6) Law, Laws of the State of Israel, vol. 27, p. 170 (1973).

${ }^{39}$ Ori Stendel, The Minorities in Israel, pp. 135-136 (1973). Henry Kamm, "Most Arabs Boycott Jerusalem Election," New York Times, January 1, 1974, p. A2.

${ }^{40}$ Basic Law: Jerusalem, Capital of Israel, Laws of the State of Israel, vol. 34, p. 209 (1980).

${ }^{41}$ Security Council Resolution 478, U.N. Security Council Official Records, 35 th year, Resolutions \& Decisions, p. 14, U.N. Doc. S/INF/36 (1981). General Assembly Resolution 35/169 (E), U.N. General Assembly Official Records, 35th session, Resolutions \& Decisions, p. 28, U.N. Doc. A/35/48 (1981).

${ }^{42}$ John Kifner, "Hussein Surrenders Claims on West Bank to the P.L.O.", New York Times, August 1, 1988, p. A1. 
Palestinian territory with its capital Jerusalem." 43 The Council projected its state for the Gaza Strip and the West Bank, including East Jerusalem. ${ }^{44}$ Thus, the reference to Jerusalem as capital was an apparent reference to East Jerusalem.

In connection with an incident that occurred in October 1990, Israel reaffairmed its claim to East Jerusalem. During an episode of shooting near the Al-Aqsa mosque by Israeli police, seventeen Palestine Arabs were killed. The U.N. Security Council condemned the killings and asked the Secretary General to report on appropriate measures to be taken. The Council reaffirmed, as the basis for international action, its previous position that East Jerusalem was under belligerent occupation. ${ }^{45}$

Israel rejected the resolution on the grounds that East Jerusalem was under its sovereignty, and therefore that the rules of belligerent occupation did not apply. In addition, Israel refused admission to a team the Secretary General wanted to send to East Jerusalem to investigate. To explain its refusal, Israel told the Secretary General, "Jerusalem is not, iny any part, 'occupied territory'; it is the sovereign capital of the State of Israel. Therefore, there is no room for any involvement on the part of the United Nations in any matter relating to Jerusalem." 46

This reaction by Israel promoted the Security Council to pass a follow-up resolution, in which it expressed "alarm" at Israel's rejection of the previous resolution. ${ }^{47}$ The Secretary General issued his report, without being able to conduct an on-site inquiry, and proposed a permanent U.N. role to monitor Israel's treatment of the Palestine Arabs in the Gaza Strip and West Bank, including East Jerusalem. 48

${ }^{43}$ Palestine National Council, Declaration of Independence, November 15, 1988, U.N. General Assembly Official Records, 43rd session, Annex 3 (Agenda Item 37) p. 13, U.N. Doc. A/43/827, S. 20278 (1988),

${ }^{44}$ Letter dated 16 November 1988 from the Deputy Permanent Observer of the Palestine Liberation Organization to the United Nations addressed to the Secretary-General, U.N. General Assembly (Official Records, 43rd session, Annex 2 (Agenda Item 37) p. 7, U.N. Doc. A/43/827, S/29278 (1988).

${ }^{45}$ Security Council Resolution 672, U.N. Doc. S/RES/672 (1990), reprinted in New York Times, October 14, 1990, p. A10.

${ }^{46}$ Report Submitted to the Security Council by the Secretary-General in Accordance with Resolution 672, 13, U.N. Doc. S/21919 (1990), reprinted in AI-Fajr Jerusalem Palestinian Weekly, November 12, 1990, p. 8.

${ }^{47}$ Security Council Resolution 673, U.N. Doc. S/RES/673 (1990), New York Times, October 26, 1990, p. A11.

${ }^{48}$ Report Submitted to the Security Council, supra note 46 . 
Around 1990 large numbers of Soviet Jews migrated to Israel, and many settled in Jerusalem, in both the west and east sectors. The Isracli Government announced plans to build new housing in East Jerusalem for these new immigrants. U.S. President George Bush said that Israel should create no "new settlements" in East Jerusalem. ${ }^{49}$ The United States Department of State reaffirmed that East Jerusalem was part of the West Bank, not of Israel. ${ }^{50}$ This new settlement activity was evidently aimed at strengthening Israel's grasp on East Jerusalem. 51

Simcha Dinitz, head of the Jewish Agency, which helped finance the Soviet Jewish migration to Israel, said that the Soviet immigrants would "give Israel the numbers it needs to go to the negotiating table from a position of strength." 52 The statement suggested that Israel viewed the arrival of the Soviet Jews as an opportunity to create facts on the ground in East Jerusalem that would make it more difficult for the state of Palestine to claim it.

The United States promised Israel a $\$ 400$ million loan to build housing for Soviet Jews but demanded an assurance that Isracl not settle the immigrants in East Jerusalem, or elsewhere in the West Bank. After several months of negotiations, Israel refused to give the assurances, but the United States released the $\$ 400$ million nonetheless. 53

In 1992, President Bush agreed with Israel to provide \$ 10 billion in additional loans for settling new immigrants. The loans were to be extended each year, and President Bush indicated that the United States would each year reduce the amount of the loans for that year by the amount Isracl might spend on the construction of housing for Jews in East Jerusalem or elsewhere in the West Bank. The amounts deducted for Isracli construction in east Jerusalem,

49"Excerpts of President Bush's Remarks at News Conference at End of Talks," Yew York Times, March 4, 1990, p. A22.

${ }^{50}$ Joel Brinkley, "Labor Party Rejects Likud Terms for Palestinian Talks," New York Times, March 6, 1990, p. A3.

${ }^{51}$ PLO Radio Broadcasts Intifadah Call No. 58, British Broadcasting Corp., Summary of World Broadcasts, June 18, 1990, pt, 4, p. ME/0793/A/1 (quoting text of Call No. 58 issued by Unified National Leadership of the Uprising).

52 Herb Keinon, "Finland Gives Go-ahead to Fly Jews to Isracl," Jerusalem Post (international edition), week ending July 14, 1990, p. 3.

${ }^{53}$ Allison Kaplan, Alisa Odenheimer \& David Makovsky, "U.S. Gave Loan Guarantees Without the Facts It Sought," Jerusalem Post (international edition), week ending March 2, 1991, p. 1. 
however, have been minimal. In 1993 the United States deducted only \$ 6.5 million on this ground, and in 1994 it deducted nothing. ${ }^{54}$

The deductions have been minimal despite the fact that Isracl has constructed new housing at a rapid rate in and around Jerusalem. In 1995, it confiscated additional Palestinian land and announced plans for a new round of settlement construction that appeared to be aimed at creating what Israeli officials called "Greater Jerusalem," extending from Ramallah in the north to Al-Khalil in the south. Isracl evaded larger reductions by the United States by giving much of the construction over to private contractors. The United States had said it would make deductions only for housing built by the Israeli government. 55

\section{Sovereignty in Jerusalem:}

Isracl gained control of west Jerusalem as part of its unlawful military actions of 1948, whereby it acquired control of the territory of the bulk of Palestine. As various states recognized Isracl as a state in the 1940s and 1950 s, they did not recognize Isracli sovereignty over West Jerusalem. ${ }^{56}$ Few states located embassies in west Jerusalem, placing them instead in Tel Aviv. After more than four decades of Isracli de facto control of West Jerusalem, the status of West Jerusalem remains unresolved. Although Israel has declared Jerusalem to be its capital city, all but a handful of states have continued to refuse to locate their embassies there, despite Israel's strong desire that they do so.

The issue of sovereignty in Jerusalem is coextensive with the question of sovereignty in Palestine. Palestine belongs to its inhabitants, on the basis of their long-time occupation. Rights are not lost when a population is forced out of its territory. Thus, the incipient state of Palestine, provisionally recognized by the League of Nations, in its population composition prior to the forced expulsions of 1948 , carries the right of sovereignty.

54 Geoffrey Aronson, U.S. Policy Shifts on Settlements, Report on Isracli Settlement in the Occupied Territories, vol. 4, no. 6, p. 1 (November 1994).

${ }^{55}$ Caryle Murphy, "Israel Girdling Jerusalem with New Jewish Housing," Washington Post, December 13, 1994, p. A29.

${ }^{56}$ Statement of U.S. Secretary of State John F. Dulles, Department of State Bulletin, vol. 30, p. 329 (1954). "The International Status of Palestine," Journal du droit international, vol. 90, p. 976 (1963). Shlomo Slonim, "The United States and the Status of Jerusalem 1947. 1984," Israel Law Review, vol. 19, pp. 179-252 (1984). 
One approach to the negotiations is to seek a formula for joint control between Israel and Palestine over east Jerusalem. ${ }^{57}$ This approach would achieve a result inconsistent with the legal rights of the parties. If one follows the legal rights, then Israel has no role in the governance of East Jerusalem.

The U.N. General Assembly in 1947 proposed still another solution for Jerusalem, namely that it become a corpus separatum under international control, and part of neither a Jewish nor an Arab state. ${ }^{58}$ If a plan is tabled for either the internationalization of East Jerusalem, or for joint control between Israel and Palestine, it should be done only with the consent of Palestine, as the state holding sovereignty over Jerusalem.

\section{Transitional Arrangements:}

Pending a settlement of Jerusalem's status, the fact that the Palestine Arab's sovereignty right remains to be effectuated has immediate consequences. Under Article 73 of the United Nations Charter, the United Nations has oversight powers to determine whether status administering nonself-governing territories are fulfilling their responsibilities to the inhabitants. Where a party other than the legitimate sovereign exercised control of a territory, a situation of non-self-governance arises.

The international community has a role as well on the basis that East Jerusalem is territory under belligerent occupation. The Geneva Civilians Convention regulates belligerent occupation and specifies (Article 1) that all states parties must ensure respect for the Convention whenever and wherever it is applicable. ${ }^{59}$ Thus, the more than 160 states that adhere to the Geneva Civilians Convention bear a collective responsibility to stop Israel's ongoing encroachment by construction and by the settlement of its citizens in East Jerusalem.

\section{Conclusion:}

The parties that initiated the negotiations leading to the 1993 Declaration of Principles have put considerable pressure on the authorities of

57 John V. Whitbeck, "Two States, One Holy Land: A Framework for Peace," Middle East International, June 14, 1991, p. 18 (proposing Jerusalem, as a joint capital of Israel and Palestine).

${ }^{58}$ General Assembly Resolution 181, 2 U.N. General Assembly Official Records, 2nd session, Resolutions p. 131, pt. 3, U.N. Doc. A/519 (1947).

${ }^{59}$ Convention Relative to the Treatment of Civilian Persons in Time of War, art. 1, August 12, 1949, U.N. Treaty Series, vol. 75, p. 287 (1950). 
the state of Palestine to convince them to cede rights that they hold. Palestine was offered limited autonomy for a transitional period only if it agreed to forego negotiations for three years on three key issues: Jerusalem, Isracl's settlements, and the retum of refugees.

The international community should promote for Jerusalem a solution consistent with the legitimate claims of the contending parties. From the standpoint of territorial right, as this notion is understood in international law, Palestine has a valid claim to Jerusalem. That does not mean that it could not agree to a solution whereby the city would be internationalized, or whereby Jerusalem were controlled jointly by Israel and Palestine. Jerusalem is one issue among several to be resolved between Palestine and Israel, and the parties are free to make concessions on the issue in order to gain an advantage on another. Palestine's valid claim to East Jerusalem, however, means that no territorial settlement can be imposed against the will of Palestine. 